\title{
Organogenesis in Carnation
}

\author{
Les Frey and Jules Janick \\ Purdue University, 1165 Horticulture Building West Lafayette, IN 47907-1165
}

Additional index words. Dianthus caryophyllus, histology, somaclonal variation, thidiazuron, tissue culture

\begin{abstract}
Shoot regeneration in carnation (Dianthus catyophyllus L.) was influenced by genotype, explant source, and plant growth regulator balance. Plants were regenerated from petals, calyxes, nodes, internodes, and leaves, but only petals, calyxes, and nodes were regenerative from all three cultivars examined ('Scania', 'Improved White Sire', 'Sandra'). Maximum proliferation was achieved with petals on Murashige and Skoog medium supplemented with $0.05 \mu_{M}$ TDZ and $0.5 \mu \mathrm{M} N A$. Shoot initiation originated from cells near vascular regions and perhaps from epidermal cells in petals and via organogenic callus from other explants. There was no evidence of chimeral separation from petals or callus, but somaclonal variants $(3.3 \%)$ were observed involving petal hue and plant dwarfness. Unstable color patterns were observed in tissue-cultured regenerants of 'Scania' and 'Improved White Sire' similar in type and frequency to propagules derived from cuttings; none were observed for tissue-cultured or cutting-derived plants of 'Sandra'. Chemical names used: N-pheny1-N'-1,2,3 -thiadiazol-5-ylurea [thidiazuron (TDZ)]; 1-napthaleneacetic acid (NM).
\end{abstract}

Organogenesis refers to the de novo differentiation of callus or other tissues into adventitious meristems that can form stems, leaves, roots, and, ultimately, plants (Pillai and Hildebrandt, 1969). Organogenesis can be exploited for genetic transformation, for chimeral separation, and as a rapid means of plant propagation if frequency of somaclonal variation is low. In carnation, organogenesis can occur from various explants, including hypocotyls (Petru and Landa, 1974), internodes (Radojevic et al., 1989), leaves (Takeda, 1978), and petals (Gimelli et al., 1982, 1983, 1984a, 1984b; Kakehi, 1979; Leshem, 1986). In this study, we have compared regeneration potential of several explants (petals, calyxes, nodes, internodes, and leaves) from three carnation cultivars;

\section{Materials and Methods}

Tissue culture protocols. Stock plants of 'Scania', 'Improved White Sire', and 'Sandra' were grown in a greenhouse maintained at $16 / 10 \mathrm{C}$ (day/night) under natural light with supplemental light provided from incandescent bulbs to interrupt winter nights. Explants were disinfested for $30 \mathrm{sec}$ in $80 \%$ ethanol, and surface sterilized for $30 \mathrm{~min}$ in a $0.5 \%(\mathrm{v} / \mathrm{v})$ solution of $\mathrm{NaOCl}$ containing a few drops of Tween 20. Tissues were rinsed four to five times with sterile distilled water. Floral buds (10 to $12 \mathrm{~mm}$ in diameter) were separated into calyx and individual petals. The petals were explanted either entire or trisected (Fig. $1)$, and the calyx was cut into pieces $(5 \times 5 \mathrm{~mm})$. Nodal segments were dissected to remove axillary buds and explanted on the agar, whereas intemodal segments from the top $46 \mathrm{~cm}$ of stock plants were cut into pieces $10 \mathrm{~mm}$ long and explanted horizontally on the medium. Young leaves were cut into $1-\mathrm{cm}^{2}$ pieces and explanted both ad- and abaxially on the culture surface.

Explants were first cultured in $60 \times 15$-mm petri plates containing $10 \mathrm{ml}$ of initiation medium consisting of Murashige and Skoog (1962) salts (Sigma, St. Louis), 87.6 mm sucrose, 26.6 $\mu \mathrm{M}$ glycine, $0.3 \mu \mathrm{M}$ thiamine- $\mathrm{HCl}, 4.1 \mu \mathrm{M}$ nicotinic acid, 2.4 $\mu \mathrm{m}$ pyridoxine- $\mathrm{HCl}, 0.6 \mathrm{~mm}$ i-inositol; and $1.0 \mathrm{~g}$ casein hydro-

Received for publication 7 Feb. 1991. Journal paper no. 12,818 of the Purdue Univ. Agriculture Experiment Station. We gratefully acknowledge the assistance in portions of this research by Anna Whipkey, W.R. Woodson, Amanda Brandt, C.E. Bracker, and the Electron Microscopy Center. The cost of publishing this paper was defrayed in part by the payment of page charges. Under postal regulations, this paper therefore must be hereby marked advertisement solely to indicate this fact.

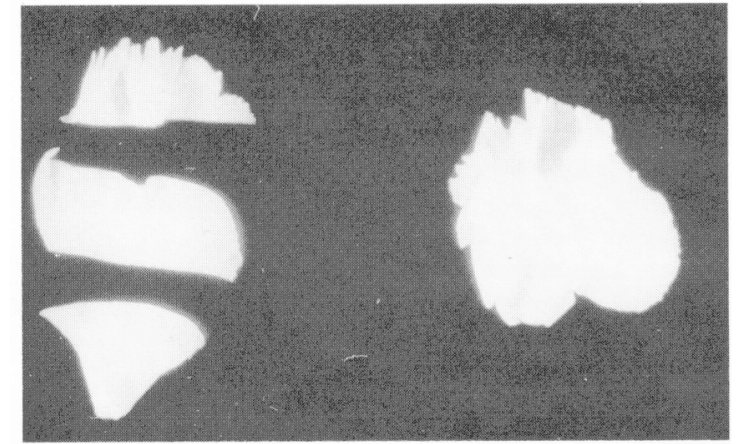

Fig. 1. Excised carnation petals before explanting; trisected petal (left), entire petal (right).

lysate and $6 \mathrm{~g}$ agar (Sigma) per liter. The medium was supplemented with $0.0,0.5$, or $5.0 \mu \mathrm{M} \mathrm{TDZ}$ and $0.0,0.5$, or $5.0 \mu \mathrm{M}$ $\mathrm{NAA}$, and the $\mathrm{pH}$ adjusted to 5.8 before autoclaving for $20 \mathrm{~min}$ at $120 \mathrm{kPa}$. Cultures were kept at $25 \mathrm{C}$ in a growth room with a 16-h photoperiod provided by cool-white fluorescent lights $\left(160 \mu \mathrm{mol} \cdot \mathrm{m}^{-2} \cdot \mathrm{s}^{-1}\right.$ photosynthetic photon flux density) until the rooting and acclimatization stages. Viable callus from leaves, internodes, nodes, and calyxes was then subculture in $70 \times$ 50-mm-diameter glass (baby food) jars containing regeneration medium (MS medium supplemented with $0.5 \mu \mathrm{M}$ TDZ and 5.0 $\mu \mathrm{M} N A A)$.

Rooting and acclimatization. Regenerated shoots were rooted on half-strength MS medium without plant growth regulators. Rooted shoots were then transferred to individual cells in plastic trays containing a greenhouse potting mix $[1$ soil :2 peat $: 2$ perlite (by volume) plus $60 \mathrm{mg}$ each of superphosphate and magnesium sulfate $/ \mathrm{kg}$, adjusted to $\mathrm{pH}$ 6.0]. Trays were enclosed within clear polyethylene bags and transferred to a growth chamber with 12-h days (25C) and nights (16C) with light provided by cool-white fluorescent bulbs $\left(95 \mu \mathrm{mol} \cdot \mathrm{m}^{-2} \cdot \mathrm{s}{ }^{-1}\right)$. Plastic covers gradually were removed over 1 month and the trays, after being completely uncovered for several days in the growth chamber, were transferred to the greenhouse. Plants that survived acclimatization were transplanted after 5 to 10 weeks and grown to flowering, receiving daily irrigation with a fertilizer solution containing $200 \mathrm{mg}$ each $\mathrm{N}$ and K/liter (pH 6.8).

\section{Results and Discussion}

Regeneration of shoots. Petals, explanted on day 0, showed enlargement on day 1 and continued to expand until about day 
Table 4. Effects of cultivar, explant source, NAA, and TDZ concentration on shoot formation from carnation explants.

\begin{tabular}{|c|c|c|c|c|c|c|}
\hline \multirow{2}{*}{$\begin{array}{l}\text { NAA } \\
(\mu \mathrm{M})\end{array}$} & \multirow{2}{*}{$\begin{array}{l}\text { TDZ } \\
(\mu \mathrm{M})\end{array}$} & \multicolumn{5}{|c|}{ Shoot formation $(\%)^{\mathbf{z}}$} \\
\hline & & Petalsy & Calyxesx & Nodesw & Internodes ${ }^{v}$ & Leaves $^{u}$ \\
\hline & & & & $\sim$ & & . \\
\hline \multirow[t]{3}{*}{0.0} & 0.0 & 0 & 0 & 0 & 0 & 0 \\
\hline & 0.5 & 100 & 0 & 10 & 0 & 0 \\
\hline & 5.0 & 85 & 0 & 0 & 0 & 0 \\
\hline \multirow[t]{3}{*}{0.5} & 0.0 & 86 & $\mathbf{0}$ & 0 & 0 & 0 \\
\hline & 0.5 & 77 & 33 & 0 & 0 & 0 \\
\hline & 5.0 & 93 & 0 & $\mathbf{0}$ & 0 & 0 \\
\hline \multirow[t]{4}{*}{5.0} & 0.0 & 85 & 0 & 10 & 0 & 0 \\
\hline & 0.5 & 92 & $33:$ & 10 & 0 & .67 \\
\hline & 5.0 & 77 & 0 & 0 & 0 & 0 \\
\hline & $\therefore$ & \multicolumn{5}{|c|}{ Improved White Sim } \\
\hline \multirow[t]{3}{*}{0.0} & 0.0 & 0 & 0 & 0 & 0 & 0 \\
\hline & 0.5 & 73 & 0 & 10 & 0 & 0 \\
\hline & 5.0 & 72 & 0 & 0 & 0 & 0 \\
\hline \multirow[t]{3}{*}{0.5} & 0.0 & 58 & 0 & 10 & 0 & 0 \\
\hline & 0.5 & 76 & 0 & 0 & 0 & 0 \\
\hline & 5.0 & 87 & 0 & 0 & 0 & 0 \\
\hline \multirow[t]{4}{*}{5.0} & 0.0 & 46 & 0 & 10 & 0 & 0 \\
\hline & 0.5 & 70 & 67 & 10 & 13 & 0 \\
\hline & 5.0 & 92 & 0. & 0 & 0 & 0 \\
\hline & & \multicolumn{5}{|c|}{ Sandra } \\
\hline \multirow[t]{3}{*}{0.0} & 0.0 & 0 & 0 & 0 & 0 & 0 \\
\hline & 0.5 & 23 & 0 & 10 & 0 & 0 \\
\hline & 5.0 & 35 & 0 & 0 & 0 & 0 \\
\hline \multirow[t]{3}{*}{0.5} & 0.0 & 0 & 0 & 0 & 0 & 0 \\
\hline & 0.5 & 30 & 0 & 0 & 0 & 0 \\
\hline & 5.0 & 56 & 0 & 20 & 0 & 0 \\
\hline \multirow[t]{3}{*}{5.0} & 0.0 & 0 & 0 & 0 & 0 & 0 \\
\hline & 0.5 & 23 & 33 & 0 & 0 & 53 \\
\hline & 5.0 & 31 & 0 & 0 & 0 & 0 \\
\hline
\end{tabular}

${ }^{2}$ Shoot regeneration differences between cultivars and explant types are significantly different at $P=0.01$ based on $x^{2}$ analysis of presence or absence of shoots.

Sixteen days in culture, trt $\mathrm{n}=10-19$.

Eighty days in culture, trt $\mathrm{n}=3$.

Forty-Wo days in culture, trt $\mathrm{n}=10$.

Eighty days in culture, trt $\mathrm{n}=15$.

"Fifty days in culture, trt $\mathrm{n}=15$.

7. On day 3, the 'Scania' and 'Sandra' petals, which were white in the bud, turned red and pink, respectively; 'Improved White Sire' petals remained white. On day 5, petal bases of all cultivars were green. Shoot formation was first visible from 'Improved White Sire' petals on day 9, from 'Scania' petals on day 12 , and from 'Sandra' petals on day 35. Shoot proliferation and growth in 'Improved White Sire' and 'Scania' continued as the petals slowly senesced and turned brown. All petals appeared limp and necrotic by day 28 .

Shoot regeneration from petals depended on cultivar and TDZ-
Table 2. Effects of cultivar, NAA, and TDZ concentration on the number of shoots formed per carnation petal explant after 29 days. Each treatment contained 15 explants.

\begin{tabular}{|c|c|c|c|}
\hline \multirow{3}{*}{$\begin{array}{l}\text { NAA } \\
(\mu M)\end{array}$} & \multicolumn{3}{|c|}{ Mean no. of shoots/explant $\pm S E$} \\
\hline & \multicolumn{3}{|c|}{$\operatorname{TDZ}(\mu \mathrm{M})$} \\
\hline & 0.0 & 0.5 & 5.0 \\
\hline $\begin{array}{l}0.0 \\
0.5 \\
5.0\end{array}$ & $\begin{array}{l}0.0 \pm 0.0 \\
8.1 \pm 2.2 \\
3.6 \pm 1.5\end{array}$ & $\begin{array}{c}\text { Scania } \\
9.4 \pm 1.8 \\
15.0 \pm 2.8 \\
13.4 \pm 2.3\end{array}$ & $\begin{array}{l}10.4 \pm 2.2 \\
13.2 \pm 1.9 \\
14.1 \pm 2.0\end{array}$ \\
\hline $\begin{array}{l}0 . \dot{0} \\
0.5 \\
5.0\end{array}$ & $\begin{array}{l}0.0 \pm 0.0 \\
7.5 \pm 1.6 \\
3.6 \pm 1.3\end{array}$ & $\begin{array}{c}\text { roved White } \\
15.0 \pm 3.9 \\
14.2 \pm 4.0 \\
18.2 \pm 5.0\end{array}$ & $\begin{array}{l}13.9 \pm 3.2 \\
19.7 \pm 1.9 \\
20.0 \pm 3.5\end{array}$ \\
\hline $\begin{array}{l}0.0 \\
0.5 \\
5.0\end{array}$ & $\begin{array}{l}0.0 \pm 0.0 \\
0.0 \pm 0.0 \\
0.0 \pm 0.0\end{array}$ & $\begin{array}{c}\text { Sandra } \\
0.3 \pm 0.2 \\
0.7 \pm 0.4 \\
0.3 \pm 0.3\end{array}$ & $\begin{array}{l}0.5 \pm 0.2 \\
1.2 \pm 0.4 \\
1.0 \pm 0.5\end{array}$ \\
\hline
\end{tabular}

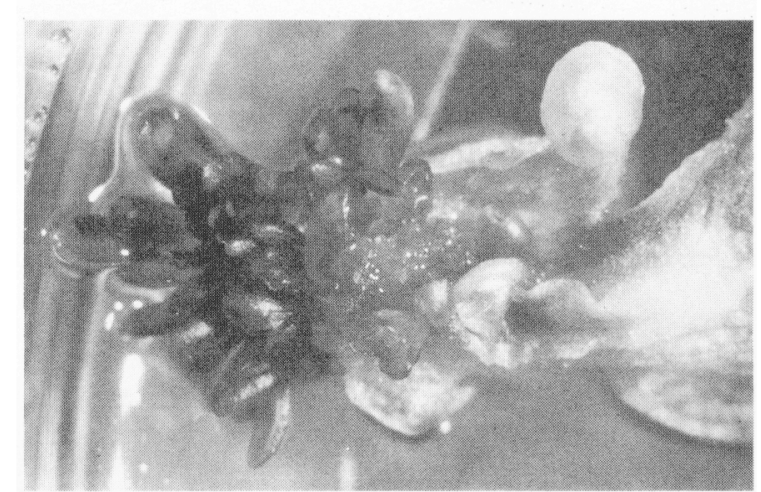

Fig. 2. Shoots developing from 'Scania' petal base after 14 days in culture.

Table 3. Effects of cultivar, petal sectioning, and section position on shoot proliferation of excised carnation petals after 25 days in culture'

\begin{tabular}{lcc}
\hline & \multicolumn{2}{c}{ Shoot proliferation } \\
\cline { 2 - 3 } $\begin{array}{l}\text { Petal } \\
\text { treatment }\end{array}$ & $\begin{array}{c}\text { Explants } \\
(\%)\end{array}$ & Mean shoots/explant \\
\hline Entire & \multicolumn{2}{c}{ Scania } \\
$\quad$ Basal end & 50 & $27.6 \pm 7.5$ \\
Trisection & & -- \\
$\quad$ Apical & 0 & -- \\
Mid & 0 & $9.9 \pm 2.8$ \\
Basal & 75 & Improved White Sim \\
& &
\end{tabular}


petals is regenerative (Alzate et al., 1990; Gimelli et al., 1982 1983, 1984a, 1984b; Kakehi, 1979; Leshem, 1986).

Light and scanning electron microscopy (Figs. 3 and 4 ) indicated that the shoot primordium developed near the petal vascular region, including bundle sheath cells, or closely related mesophyll cells (Fig. 4A), and perhaps from epidermal cells on

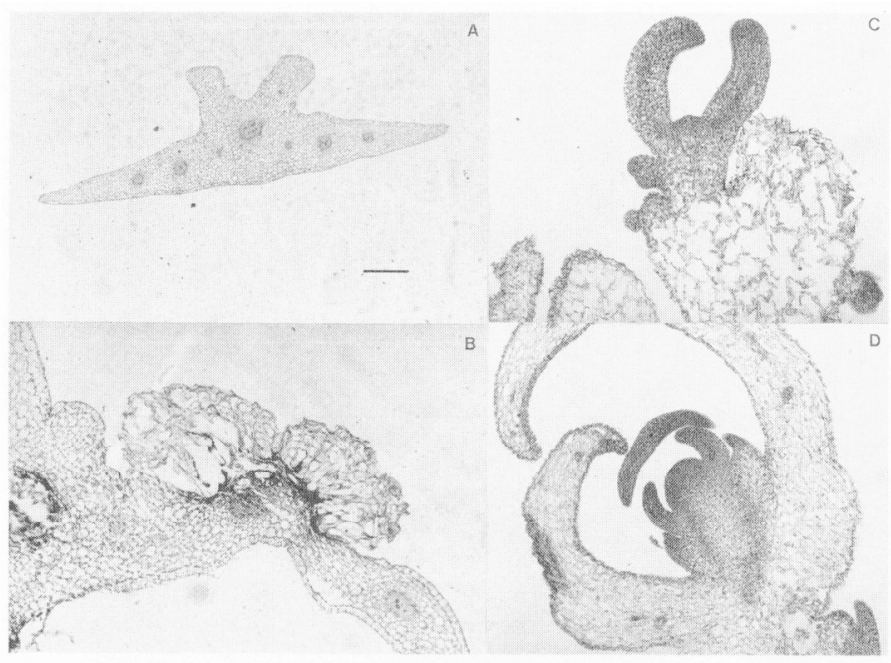

Fig. 3. Histology of organogenesis in petals: (A) cross section of petal base at day 0; (B) cellular mass emerging from vascular bundle at day $8 ;$ (C) shoot initiation from cellular mass-showing apical dome and expanding leaves at day 10; (D) apical dome with several leaf primordia at day 20. Bar $=300 \mu \mathrm{m}$. the perimeter of the petal base (Fig. 4B). Shoots were not formed from preformed meristematic cells. The first observed event was the formation of an "amorphous layer" on the basal edge (Fig. 4A), followed by the formation of proliferating callus (Figs. 3B and 4 A, B), and finally shoot initiation (Figs. $3 \mathrm{C}, \mathrm{D}$, and 4 $\mathrm{C}, \mathrm{D})$.

Callus formed on the cut surfaces of all explant types from days 8 to 11. Shoot regeneration depended on genotype and TDZ-NAA balance (Table 1). All cultivars developed shoots from calyxes and nodes, but only 'Improved White Sire' developed shoots from internodes and only 'Scania' and 'Sandra' developed shoots from leaves.

Although organogenesis was obtained from all explants studied, only petals proved to be a constant, dependable, and prolific source of shoots for all cultivars (Table 1). Regeneration from petals tended to be optimum from medium supplemented with a combination of $0.5 \mu \mathrm{M} \mathrm{TDZ}$ and $0.5 \mu \mathrm{M}$ NAA. Shoot formation appeared to arise directly from petal tissue, but SEM suggested that a transient callus phase was involved. Organogenesis was sporadic in all other explants (i.e, calyxes, nodes, internodes, and leaves) and only occurred directly from callus.

Several techniques improved shoot regeneration from petals. The most shoots were obtained by culturing petals at $30 \mathrm{C}$ on medium containing $60 \mathrm{~g}$ sucrose and $1 \mathrm{~g}$ casein hydrolysate/ liter, $0.05 \mu \mathrm{M} \mathrm{TDZ}, 0.5 \mu \mathrm{MNAA}$, and that was solidified with 8 to $10 \mathrm{~g}$ agar/liter (data not presented). However, many treatments that maximized shoot proliferation also increased vitrification. Taking both proliferation and vitrification into consideration, the optimum protocol used to maximize unvitrified shoot production from petals was as follows: Temperature,

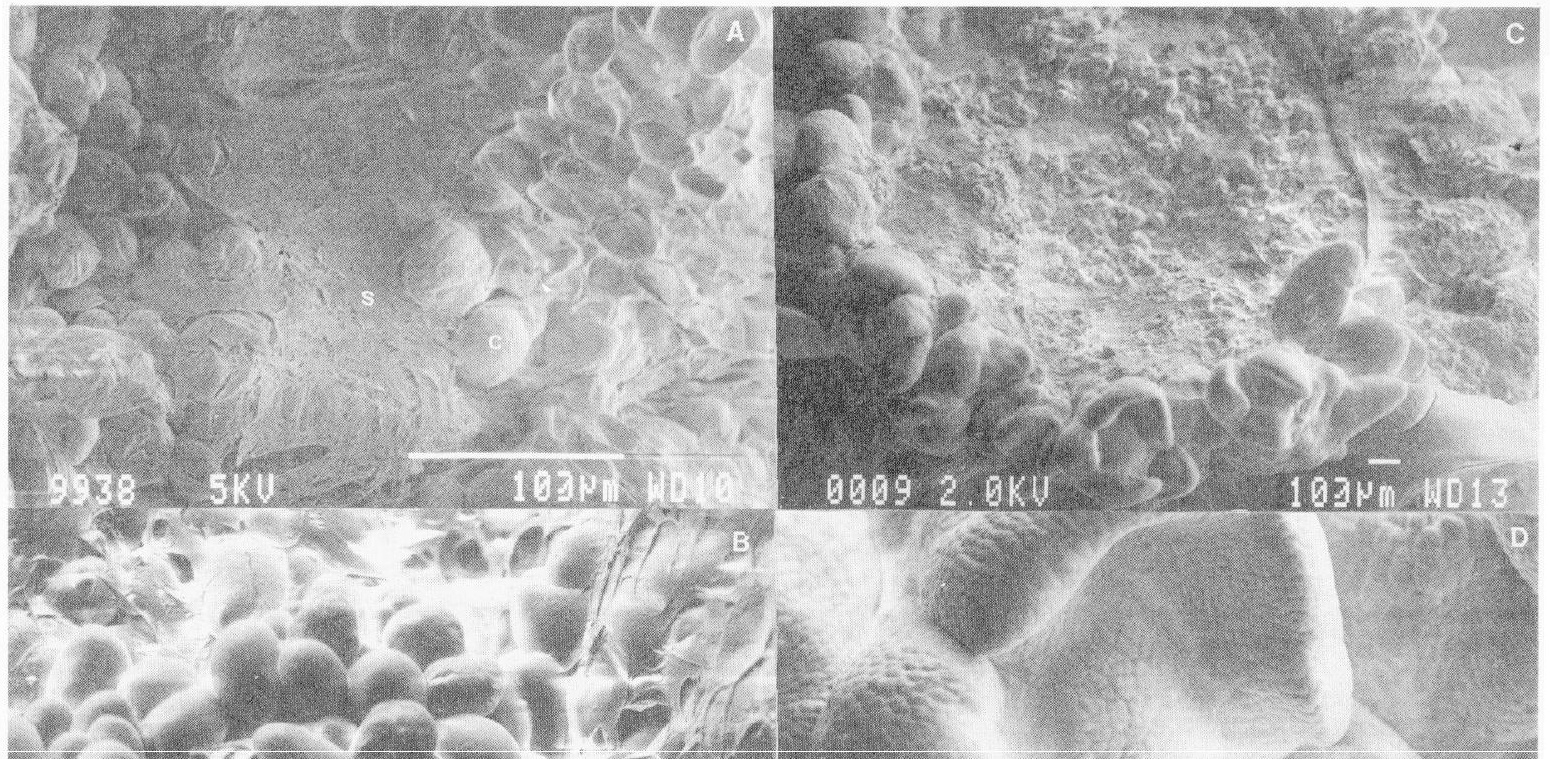




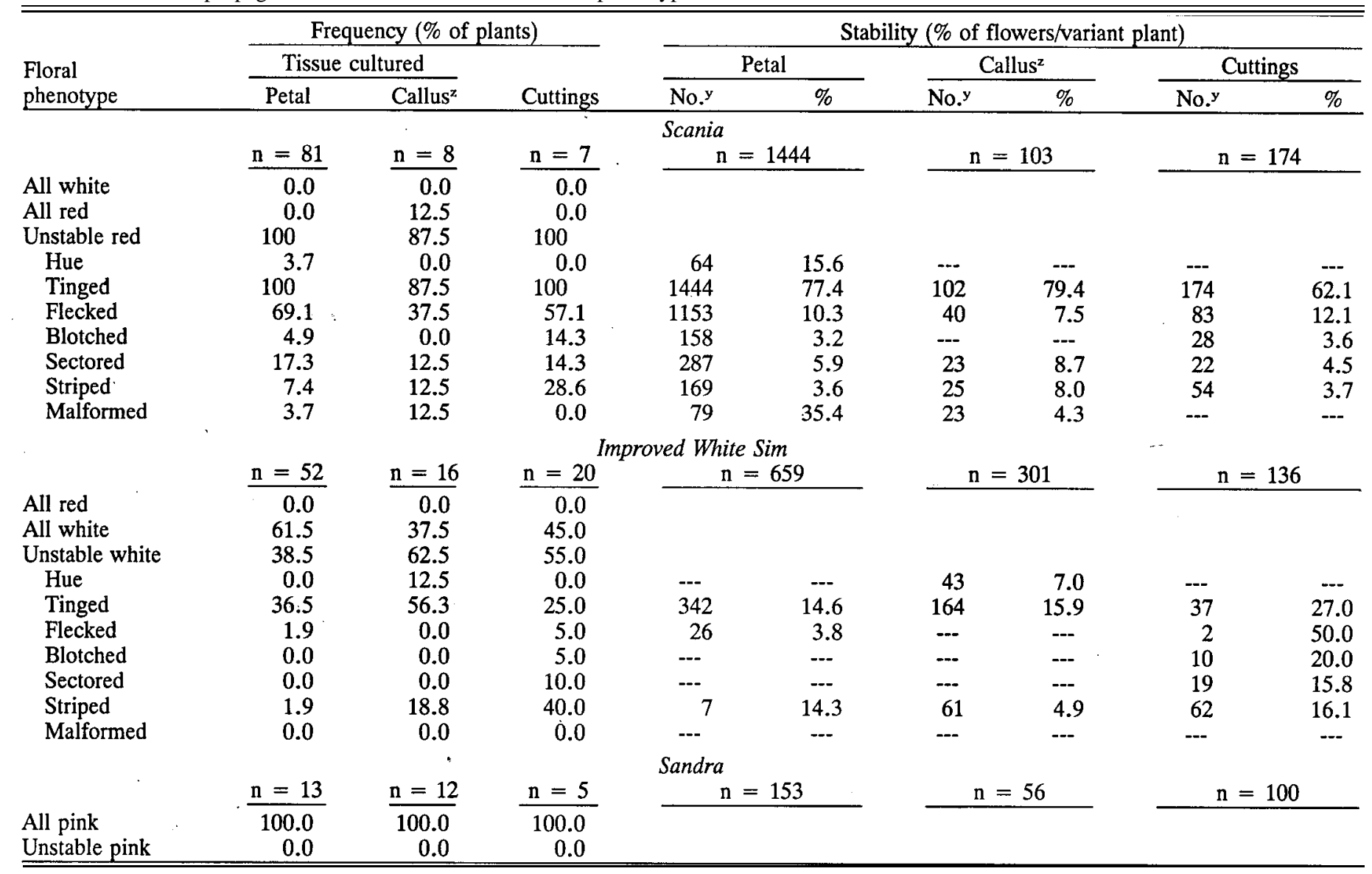

${ }^{2}$ Includes plants from leaves, internodes, nodes, or calyx.

'No. flowers that showed floral variation.

15 to $20 \mathrm{C}$; agar, 8 to $10 \mathrm{~g} \cdot$ liter $^{-1}$ sucrose, $30 \mathrm{~g} \cdot \operatorname{liter}^{-1}$; casein hydrolysate, 0 to $0.5 \mathrm{~g}$.liter ${ }^{-1}$ cytokinin, $0.05 \mu \mathrm{M} \mathrm{TDZ}$; auxin, $0.5 \mu$ MAA; culture vessel, baby food jars or Magenta GA7. Somaclonal variation. A total of 182 tissue culture-derived plants that produced 2716 flowers were evaluated for plant growth habit and flower morphology (Table 4) for 1 year. One plant derived from a 'Scania' petal was variant in growth habit with a compact, bushy form and shiny, nonglaucous leaves.

Individual flowers were examined for variations in hue, color pattern, and form in plants derived from tissue culture and cuttings (controls). Color pattern variants were visually classified as tinged, a discoloration of petals, flecked, small off-color irregular spots on the petals; sectored, a clearly defined petal sector of a variant color; striped, short streaks of a variant color traversing the petals; or blotched, similar to flecking except that flowers had larger off-color irregular patches dispersed across had one cream and 20 white flowers, whereas the nodal variant had two cream and 20 white flowers. None of the 'Scania' or 'Improved White Sire' controls were variant for pigment hue.

Stability differences in flower patterns were noted between the three cultivars: 'Sandra' was very stable, and no variants were observed in either tissue-cultured or control plants, whereas 'Scania' and 'Improved White Sire' were unstable for tissue culture-derived and control plants. There was no convincing evidence that variant phenotypes were more frequent in tissue culture-derived plants than in vegetatively propagated plants from cuttings (Table 4). Many of the floral instabilities observed in tissue-cultured 'Scania' and 'Improved White Sire' plants also were noted in parental controls at similar frequencies.

There were two classes of malformed flowers from tissue culture-derived plants: those from flowers initiated in vitro, and those from flowers initiated ex vitro. Buds that were induced in 
respect to predominant flower color, i.e., tissue-cultured 'Scania' were red with some small white spots, 'Improved White Sire' were white with small red spots, and 'Sandra' were all pink. No tissue culture-derived plants were obtained in which all flowers were of a variant color. The instability of petal color in 'Scania' and 'Improved White Sire' was similar for petal-derived, callus-derived, and vegetatively propagated plants. 'White Sire' is a periclinal chimera of 'William Sire' (Johnson, 1980; Pereau-Leroy, 1974; Sagawa and Mehlquist, 1957), and although 'Improved White Sire' is derived from 'William Sire', there are no reports confirming that it also is a periclinal chimera. However, an occasional completely red flower was noted in 'Improved White Sire' stock plants derived from cuttings. Assuming that 'Improved White Sire' is a periclinal chimera with $\mathrm{L}_{\mathrm{I}}$ being white and $\mathrm{L}_{\mathrm{II}}$ and $\mathrm{L}_{\mathrm{III}}$ being red, the expected phenotypes from tissue culture could be either 1) all-white flowers derived from $L_{1}, 2$ ) white flowers with red spots derived from a combination of $\mathrm{L}_{\mathrm{I}}$ and $\mathrm{L}_{\mathrm{II}}$, or 3 ) all-red flowers derived from $\mathrm{L}_{\mathrm{II}}$ or $\mathrm{L}_{\mathrm{III}}$. In our study, there was no evidence of complete chimeral separation in 'Improved White Sire' from either petals or callus as would have been expected from a periclinal chimera. Our observations of red flower reversion and lack of chimeral separation from organogenesis may be reconciled with one of the following assumptions: 1) 'Improved White Sire' is not a periclinal chimera and the red flowers produced by cuttings were due to a mutation. The floral patterns of 'Improved White Sire' may be a result of genetic instabilities, perhaps transposons or highly mutable genes; 2) 'Improved White Sire' is a periclinal chimera, but the $\mathrm{L}_{\mathrm{I}}$ and $\mathrm{L}_{\mathrm{II}}$ layers are genetically white and only the $\mathrm{L}_{\mathrm{III}}$ layer is genetically red. The lack of chimeral separation in 'Improved White Sire' may be explained if $\mathrm{L}_{\mathrm{III}}$ tissue is not involved in organogeneis. The red flowers observed for some 'Improved White Sire' cuttings could be due to adventitious buds derived from $\mathrm{L}_{\mathrm{II}}$.

Further studies will be needed to determine if petal regeneration could be used for a propagation system or if any of these organogenic systems can be used for genetic transformation or recovery of interesting genetic variants from different histogenic layers.

\section{Literature Cited}

Alzate, A. L., A. Angarita, and V. Montes de Gomez. 1990. Use of F. oxysporum toxic material as tolerance inductor in Dianthus car- yophyllus tissue culture. VIIth Intl. Congr. on Plant Tissue and Cell Culture, Amsterdam. 24-29 June 1990. p. 159.

Gimelli, F., G.B. Ginatta, R. Venture, and S. Positano. 1982. Effects of genotype and in vitro culture conditions on regeneration and floral induction in Mediterranean carnation (Dianthus caryophyllus L.). 8th Long Ashton Symp. Imp. Vegetatively Propagated Plants, Bristol, England. 12-15 Sept. 1982.

Gimelli, F., G.B. Ginatta, R. Venture, and M. Buiatti, 1983. Effetto del genotipo e dells fonte di espianto sulla rignerazione in garofano (Diathus caryophyllus L.). Genetics Agraria 37:175-176.

Gimelli, F. and M. Buiatti, 1984a. Potenzialita dell'uso delle colture in vitro nel miglioramento genetico del garofano. L'Informatore Agrario 13:41-46.

Gimelli, F., G. Ginatta, R. Venture, S. Positano, and M. Buiatti. 1984b. Plantlet regeneration from petals and floral induction in vitro in the Mediterranean carnation (Dianthus caryophyllus L.). Riv. Ortoflorofrutt. Ital. 68: 107-121.

Johnson, R.T. 1980. Gamma irradiation and in vitro induced separation of chimeral genotypes in carnation. HortScience 15:605-606.

Kakehi, M. 1979. Studies on the tissue culture of carnation V. Induction of redifferentiated plants from the petal tissue. Hiroshima Agr. College Bul. 6:159-166.

Leshem, B. 1986. Carnation plantlets from vitrified plants as a source of somaclonal variation. HortScience 21:320-321.

Murashige, T. and F. Skoog. 1962. A revised medium for rapid growth and bioassays with tobacco tissue cultures. Physiol. Plant. 15:473497.

Pereau-Leroy, P. 1974. Genetic interaction between the tissues of carnation petals as periclinal chimeras. Radiation Bet. 14:109-116.

Petru, E. and Z. Landa. 1974. Organogenesis in isolated carnation plant callus tissue cultivated in vitro. Biologia Plant. 16:450-453.

Pillai, S.K. and A.C. Hildebrandt. 1969. Induced differentiation of geranium plants from undifferentiated callus in vitro. Amer. J. Bet. 56:52-58

Radojevic, L., N. Djordjevic, and J. Petrovic. 1989. In vitro culture techniques for carnation cultivars breeding. Intl. Symp. In Vitro Culture and Hort. Breeding, Cesena, Italy, 30 May-3 June 1989.

Sagawa, Y. and G.A.L. Mehlquist. 1957. The mechanism responsible for some X-ray induced changes in flower color of the carnation, Diathus caryophyllus. Amer. J. Bet. 44:397403.

Takeda, Y. 1978. Carnation mubyo-nae no ikusei, p. 114-147. In: S. Kako (cd.). Enqei-shokubutu no kikan to soshiki no baiyo. Seibundo-Shinko-sha, Tokyo. [Cited in M. Mii, M. Buiatti, and T. Gimelli. Carnation, p. 284-317. In: P.V. Ammirato, D.A. Evans. W.R. Sharp, and Y.P.S. Bajaj (eds.). Handbook of plant cell tissue culture vol. 5: Ornamental species. McGraw-Hill, New York.] 